\title{
TWO SPECIES OF PONTONIID PRAWNS COMMENSAL WITH BIVALVES (CRUSTACEA, DECAPODA, PALAEMONIDAE)
}

\section{$\operatorname{AUTHOR}(\mathrm{S})$ :}

Fujino, Takahiro; Miyake, Sadayoshi

\section{CITATION:}

Fujino, Takahiro ... [et al]. TWO SPECIES OF PONTONIID PRAWNS COMMENSAL WITH BIVALVES (CRUSTACEA, DECAPODA, PALAEMONIDAE). PUBLICATIONS OF THE SETO MARINE BIOLOGICAL LABORATORY 1967, 15(4): 291-296

\section{ISSUE DATE:}

$1967-12-20$

URL:

http://hdl.handle.net/2433/175475

RIGHT: 


\title{
TWO SPECIES OF PONTONIID PRAWNS COMMENSAL WITH BIVALVES (CRUSTACEA, DECAPODA, PALAEMONIDAE) ${ }^{1)}$
}

\author{
Takahiro FUJINO and Sadayoshi MIYAKE \\ Zoological Laboratory, Faculty of Agriculture, Kyushu University
}

With 3 Text-figures

Recently the authors received some specimens of two interesting species of pontoniid prawns, Conchodytes nipponensis and Anchistus pectinis sent for examination by Dr. T. Tokioka. They happened to be found living in the mantle cavity of the bivalve, Pecten (Notorola) albicans collected from Tanabe Bay, Kii Peninsula. $C$. nipponensis is restricted to and common in Japan, while $A$. pectinis is rare as it is for the first time collected since KEMP (1925) originally recorded it in Pecten sp. from the Nicobar Islands.

The authors here try to describe the details of the latter with the illustrations of the mouthparts and colour pattern. In the material here examined are also contained some other specimens except for those from Tanabe Bay.

Before going further, the authors express their cordial thanks to Dr. Takasi Tokioka of the Seto Marine Biological Laboratory for the opportunity of studying this interesting material and information of the colour pattern. The authors' thanks are also due to Dr. Yosie DoтU of the Nagasaki University for providing us with the material.

\section{Conchodytes nipponensis (DE HAAN, 1844)}

Hymenocera nipponensis DE HAAN, 1844, pl. 46, fig. 8.

Pontonia nipponensis: DE HAAN, 1849, p. 180; Balss, 1914, p. 53, fig. 33.

Conchodytes nipponensis: PARisr, 1919, p. 74, figs. 5, 6; KeMP, 1922, p. 282, fig. 104; KuBo, 1937, p. 629, figs. 1-5; KuBO, 1940, p. 64, figs. 28, 29.

Material examined. Tanabe Bay, Wakayama Pref., 10-20 m deep, 1 o , 1 ovig. 우, ZLKU No. 9333, May 9, 1967, T. Tokioka leg.

Off Tosa-shimizu, Kochi Pref., 1 o, 1 ovig. 우, ZLKU No. 1975, Feb. 19, 1960, S. Nakayama leg.

Between Aino-shima I. and Munakata-oshima I., Fukuoka Pref., beam trawl, 5 꾸, 1 ovig. 우, ZLKU No. 2105, June 14, 1960, Y. Dotu leg.

1) Contributions from the Zoological Laboratory, Faculty of Agriculture, Kyushu University, No. 365 and Contributions from the Seto Marine Biological Laboratory, No. 474.

Publ. Seto Mar. Biol. Lab., XV (4), 291-296, 1967. (Artiçle 16) 
Off Munakata-oshima I., Fukuoka Pref., 1 ơ, 1 ovig. 우, ZLKU No. 2118, July 20, 1958, K. Ueno leg.

This species is much swollen and rather large. The present specimens measure from 12.8 ( $\sigma$ ) to 29.5 (ovig. 우) $\mathrm{mm}$ in body length.

Colour. According to Tokroka, the body is light reddish brown with small, white spots which are thickly distributed when alive. After several days have passed since the specimens were preserved in formalin red chromatophores remain clearly visible on the dorsal sides of the carapace and abdomen, and are less scattered on the other parts.

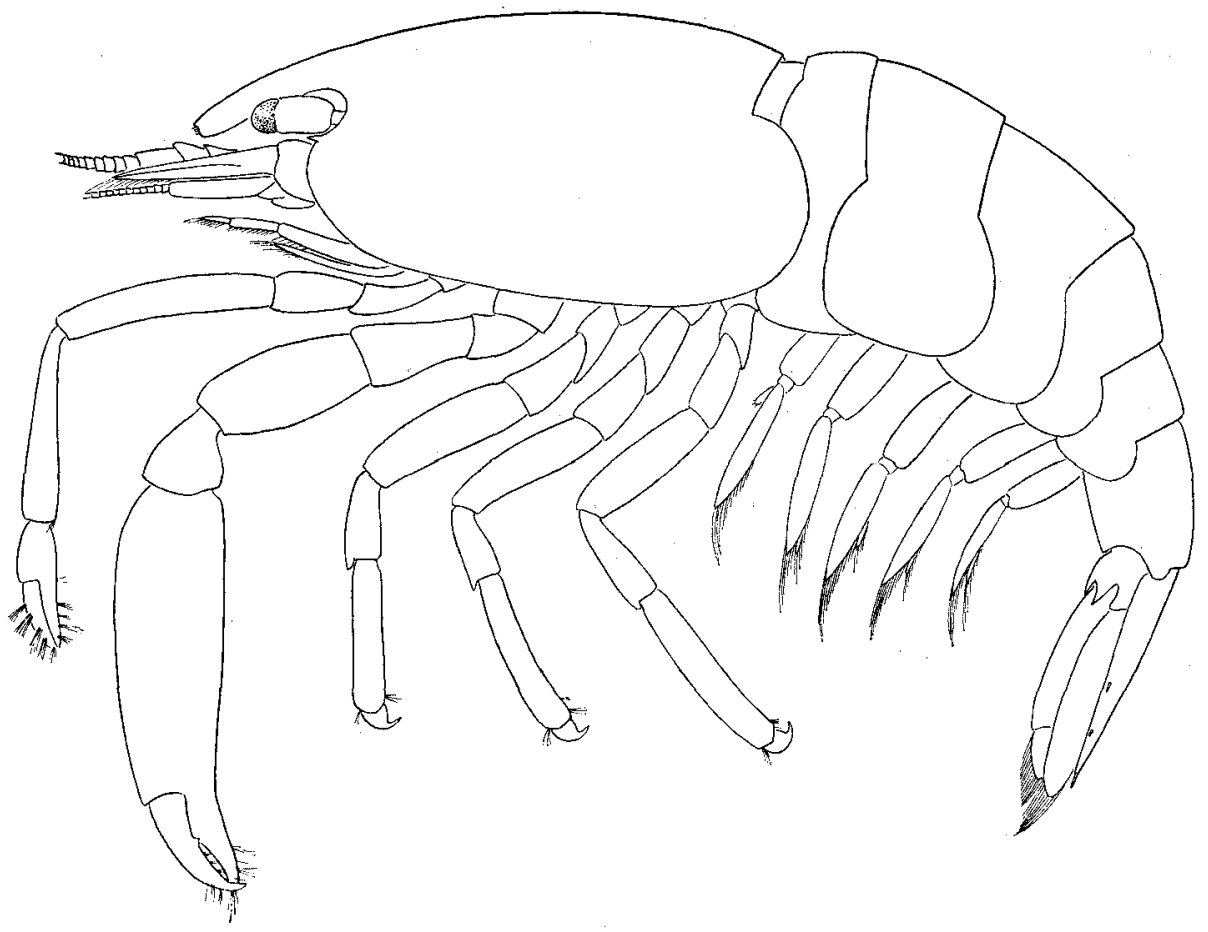

Fig. 1. Anchistus pectinis KEMP, $\times 8.8$.

Remarks. Until now another species, Conchodytes tridacnae, has been known from Japan. This species has been distinguished from $C$. nipponensis by the absence of a small tooth at the proximal end of each basal protuberance of the last three pereiopods. The tooth in some specimens of $C$. nipponensis examined is very obscure or entirely absent, but this species is easily distinguishable from $C$. tridacnae by the presence of three pairs of the dorsal spines of the telson and two pairs of spines at the terminal end of the telson.

Distribution. This species is a littoral form occurring in the depth of 10 to $20 \mathrm{~m}$, 
and it has hitherto been recorded from only Japan, namely, Chiba Prefecture, Tokyo, Sagami Bay and Aichi Prefecture.

Kuвo (1937, 1940) recorded this species in association with Pecten laquetus $[=P$. (Notovola) albicans $]$ and Atrina japonica $[=A$. (Servatrina) pectinata $]$. The specimens here examined were collected in commensal with the former.

\section{Anchistus pectinis KEMP, 1925}

(Figs. 1-3)

Anchistus pectinis KEMP, 1925, p. 327, figs. 19, 20.

Material examined. Tanabe Bay, Wakayama Pref., 10-20 m deep, 1 o , 1 우, ZLKU No. 9335, May 9, 1967, T. TокiокA leg.

Between Aino-shima I. and Munakata-oshima I., Fukuoka Pref., beam trawl, 1 우, ZLKU No. 2107, Y. Dotu leg; 1 ơ, 1 우, ZLKU No. 2120, July 20, 1958, K. UENo leg.

This species is rather small. The specimens measure from 12.0 ( $\sigma^{\circ}$ ) to 24.5 (우) $\mathrm{mm}$ in body length.

Description. The body is compressed. The rostrum is shallow and strongly curved downwards, reaching to the middle of the second segment of the antennular peduncle; the apex is truncated, and both of the upper and the lower borders lack any tooth. The carapace is smooth with only a small antennal spine; it is sunken behind the orbit, and the orbital angle is convex (Fig. 1).

The first segment of the antennular peduncle is broad; the outer margin is somewhat convex and terminates in a minute spine; the lateral process is projected round, not reaching to the middle of the second segment. The tip of the stylocerite is obtuse, barely reaching to the middle of the first segment. The second segment of the peduncle is slightly shorter and narrower than the third. The outer antennular flagellum is short and fused for four or five joints.

The antennal scale is broad, slightly more than twice as long as broad; the outer margin is somewhat convex, ending in a stout tooth extending to the end of the lamella.

The $\mathrm{Y}$-shaped mandible consists of the incisor process with four terminal teeth and the broad molar process (Fig. 2, a). The palp of the maxillule is concave distally; the proximal endite is close to the distal one and broader than the latter (Fig. 2, b). The scaphognathite of the maxilla is ear-shaped; the endopod is thumb-like, and the endite is bifid distally (Fig. 2, c). The first to third maxillipeds bear exopods and epipods. The fifth maxilliped has the broad caridian lobe of the exopod; the endopod is rather short and narrow, and the epipod is distinctly bilobed (Fig. 2, d, e). The third maxilliped is pediform, the ultimate segment of the endopod being short and half as long as the penultimate; the exopod reaches beyond the end of the antepenultimate segment; the epipod is broad, and the arthrobranch is small (Fig. 2, f). 


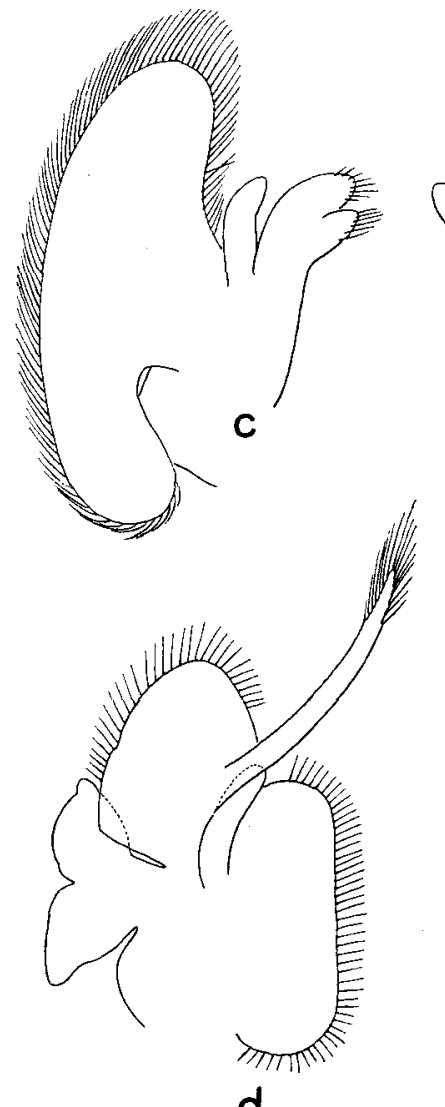

d

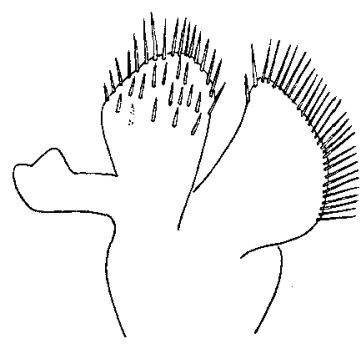

b

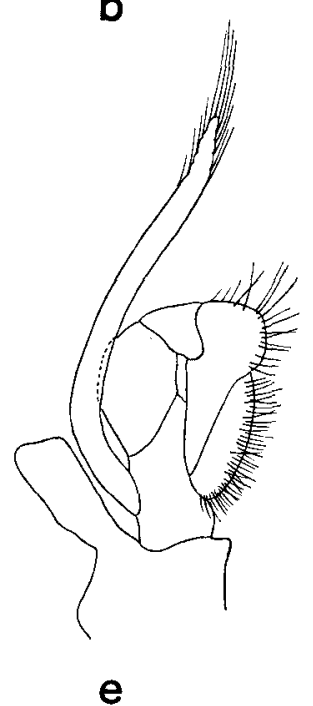

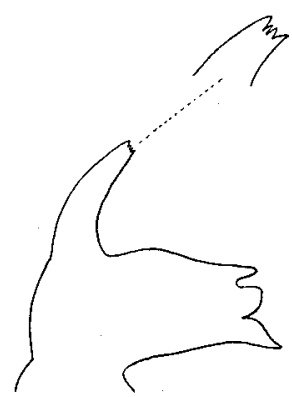

a

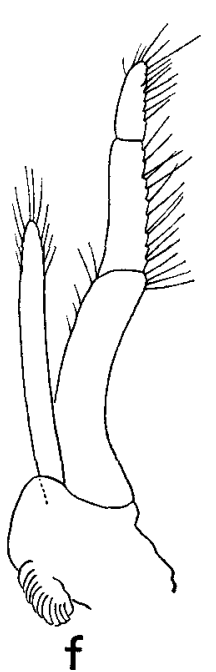

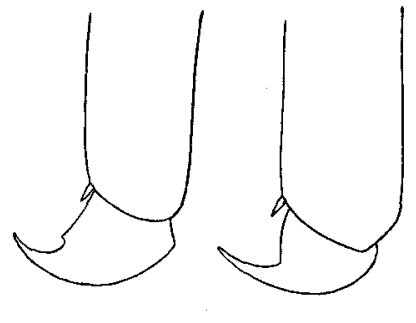

g

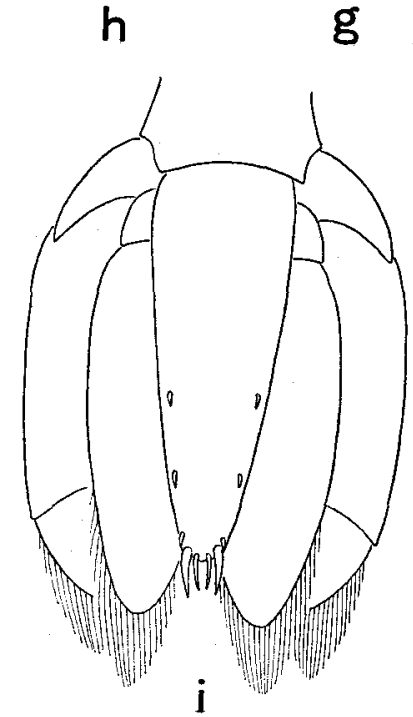

Fig. 2. Anchistus pectinis KEMP, a, mandible; b, maxillule; c, maxilla; d, first maxilliped; e, second maxilliped; $\mathrm{f}$, third maxilliped; $g$ and $h$, dactylus of third pereiopod; $i$, telson and uropods. 
The first pereiopod exceeds the antennal scale by the chela and most of the carpus. The finger is slightly shorter than the palm, and the cutting edges are thin. The carpus is subequal to the merus in length.

The second pereiopods are somewhat unequal in length. The movable finger has a strong tooth at the proximal third on the cutting edge; the tip of the movable finger is strongly curved and pointed, overhanging that of the immovable. The cutting edge of the immovable finger bears four small teeth at the proximal half, the distal one being larger than the others. The palm is rather broad, being more than three and a half the length of the movable finger. The carpus is short and conical.

The third pereiopod is rather stout and short. The dactylus is crooked deeply, being simple or with a vestigial tooth posteriorly; the base is broad and terminates in the tip with a stout claw (Fig. $2, \mathrm{~g}, \mathrm{~h}$ ). The propodus is as long as the merus, without any spine on the posterior border.

The abdomen is smooth with round pleura; the fifth pleuron is produced round posteriorly.

The telson is elongated and four times as long as broad, being shorter than twice the length of the sixth abdominal segment. Two pairs of the dorsal spines are very small; the anterior is placed a little behind the middle of the telson, and the posterior is midway between the anterior one and the hind end of the telson. The uropod is distinctly longer than the telson (Fig. 2, i).

Colour. According to TokiokA, this prawn in life is light pink in the ground colour, and purplish at the end of the chela and of the telson, with reddish circular spots somewhat closely settled. Closely examined, each spot is composed of a reddish circle with some radial lines of the same colour, looking like a wheel with spokes. The antenna is transparent. The eggs are tinged with olive (Fig. 3). In the specimen freshly

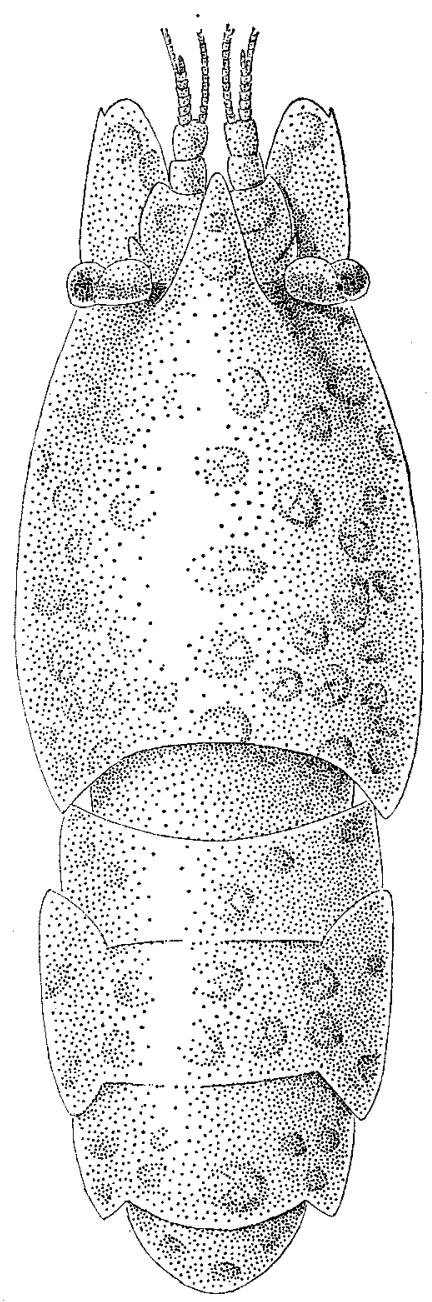

Fig. 3. Colour pattern of Anchistus pectinis KEMP. preserved in formalin the pinkish colour of the ground disappears but the pattern of the spots remains distinctly. These spots are tinged with purple or reddish purple, and in the carapace in dorsal view the situations of these spots are symmetrical but not in some degree in the abdomen. The second pereiopod is mottled with a round, 
purple patch, and with two broad stripes of the similar colour running transversely in the fingers.

Remarks. This species has not been recorded since KEMP's (1925) original description. Between the present specimens and KEMP's description distinctive differences are hardly found. In one male specimen, as described above, each dactylus of the last three pereiopods bears a minute accessory tooth at the posterior margin of the base where the claw is incurved. While in the two females the dactyli bear entirely smooth margins, without the accessory teeth. KEMP described that each dactylus of the last three pereiopods is simple without an additional tooth, though a very minute one is figured in his illustration. Therefore, as mentioned above, considerable variations may be recognized in each accessory tooth of the last three pereiopods.

This species is most closely related to Anchistus misakiensis YoкоY except for only lacking a conspicuous, proximal tooth on each dactylus of the last three pereiopods. This difference, however, is considered to be too small to separate $A$. misakiensis from $A$. pectinis, because one of the present specimens, as described above, has the vestigial tooth instead of the entire margin on the same position of the dactylus as Yokoy figured and therefore some variations are found in this character. Thus it seems probable that these species are synonymous.

Distribution. This species was only recorded originally from the Nicobar Islands together with Pecten sp. The present specimens were collected in a couple from in the mantle cavity of Pecten (Notovola) albicans from Fukuoka Prefecture and Kii Peninsula, therefore this species extends its known range farther northward to Japan.

\section{REFERENCES}

Batss, H. 1914. Ostasiatische Decapoden II. Die Natantia und Reptantia. In: Doflein, F., Beiträge zur Naturgeschichte Ostasiens. Abh. Bayer. Akad. Wiss., suppl. vol. 2, pt. 10, pp. 1-101, figs. $1-50$, pl. 1.

de HaAn, W. 1833-1850. Crustacea. In: de Stebold, P.F., Fauna Japonica sive descriptio animalium, quae in itinere per Japoniam, jussu et auspiciis superiorum qui summum in India Batava Imperium tenent, suscepto, annis 1823-1830 collegit, notis, observationibus et adumbrationibus illustravit: ix-xvi, i-xxxi, vii-xvii, 1-243, pl. A-Q, 1-55, circ. 2.

KEMP, S. 1922. Notes on Crustacea Decapoda in the Indian Museum. XV. Pontoniinae. Rec. Indian Mus., vol. 24, pt. 2, pp. 113-288, figs. 1-105, pls. 3-9.

1925. Notes on Crustacea Decapoda in the Indian Museum. XVII. On various Caridea. Rec. Indian Mus., vol. 27, pp. 249-343, figs. 1-24.

KuBo, I. 1937. On the commensal shrimps of the genus Conchodytes in the mantle-cavity of bivalves. Botany and Zoology, vol. 5, no. 3, pp. 57-60, figs. 1-5.

1940. Studies on Japanese palaemonoid shrimps. II. Pontoniinae. J. Imp. Fish. Inst., Tokyo, vol. 34 , no. 1 , pp. $31-75$, figs. 1-36.

Parisı, B. 1919. I. Decapodi giapponesi del Museo di Milano. VII. Natantia. Atti Soc. Ital. Sci. nat., vol. 58, pp. 59-99, pls. 3-6.

Yoкоул, Y. 1936. Some rare and new species of decapod Crustaceans found in the vicinity of the Misaki Marine Biological Station. Japan. J. Zool., vol. 7, pp. 129-146, figs. 1-10. 